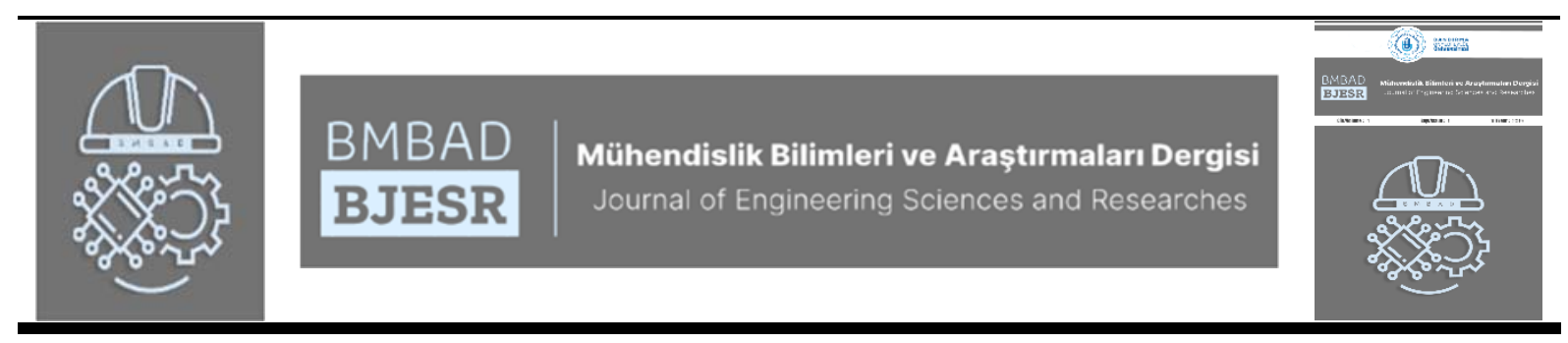

\title{
Determining Suitable Regions for Potential Offshore Wind Farms in Bandırma Bay using Multi-criteria-Decision-Making Method
}

\section{Çok-kriterli Karar Verme Metodu Kullanarak Bandırma Körfezinde Uygun Deniz Üstuii Rüzgar Enerji Santral Alanlarınun Tespiti}

\author{
${ }^{1,2}$ Fatih KARIPOĞLU $(\mathbb{D}),{ }^{3}$ Samet ÖZTÜRK ${ }^{(D)},{ }^{2}$ Mustafa Serdar GENÇ \\ 1,2 İzmir Yüksek Teknoloji Enstitüsü, Mühendislik Fakültesi, Enerji Sistemleri Mühendisliği, 35430, Urla/İzmir \\ ${ }^{2}$ Erciyes Üniversitesi, Enerji Sistemleri Mühendisliği, 38430, Kayseri, Turkey \\ ${ }^{3}$ Bursa Teknik Üniversitesi, Mühendislik ve Doğa Bilimleri Fakültesi, Çevre Mühendisliği, Yıldırım/Bursa, Türkiye \\ 2samet.ozturk@btu.edu.tr, ${ }^{1}$ fatihkaripoglu@iyte.edu.tr \\ ${ }^{3}$ musgenc@erciyes.edu.tr \\ Araştırma Makalesi/Research Article
}

A R T I C L E IN F O

Article history

Received :20 March 2021

Accepted : 7 April 2021

Keywords:

Wind Energy, Offshore, Suitable Site Selection, Multi-criteria Method
A B S T R A C T

Wind energy is an environmentally friendly, profitable, and renewable energy resource. Wind energy deployment is increasing in the last two decades. In this paper, Bandirma bay which has a potential for offshore wind deployment is studied to determine the most suitable area in it and eventually potential offshore power capacity of the location is estimated. This study combines applications of Geographical Information System and Multi-CriteriaDecision-Making Methodology to obtain fast results supported with visual documentation. In this scope, eight standard criteria such as wind speed, water depth, bird migration lines are applied and investigated in detail by using Geographical Information System. It is found that there is sufficient wind speed at the shallow level of the sea. Consequently, two locations are found to be suitable; one is on the northwest and the other one is on the north east of Bandirma, with capacities of $72 \mathrm{MW}$ and $48 \mathrm{MW}$, respectively.

(C) 2020 Bandirma Onyedi Eylul University, Faculty of Engineering and Natural Science. Published by Dergi Park. All rights reserved.

M A K A L E B İ L G İ S İ

Makale Tarihleri

Gönderim : 20 Mart 2021

Kabul : 7 Nisan 2021

\section{Anahtar Kelimeler:}

Rüzgar Enerjisi, Deniz Üstü, Uygun Alan Seçimi, Çokkriterli Method

\section{Ö Z E T}

Rüzgar enerjisi çevre dostu, karlı ve yenilenebilir bir enerji kaynağıdır. Rüzgar enerjisi yayılımı son yirmi yılda artmaktadır. Bu çalışmada, deniz üstü rüzgar yayılımı potansiyeli olan Bandırma körfezi içindeki en uygun alanın belirlenmesi için çalışılmış ve sonuç olarak buradaki potansiyel deniz üstü güç kapasitesi tahmin edilmiştir. Bu çalışma, görsel ve hızlı analiz sonuçlarını elde etmek için Coğrafi Bilgi Sistemi ve Çok-Kriterli-Karar-Verme Metodolojisi metodlarını birlikte kullanmaktadır. Bu kapsamda rüzgar hızı, deniz derinliği, kuş göç hatları gibi sekiz standart kriter uygulanarak detaylı bir şekilde Coğrafi Bilgi Sistemi kullanılarak incelenmektedir. Bandırma'nın deniz trafiği yoğunluğunun yüksek olması nedeniyle uygun bölge seçiminde gemi rotaları önemli ölçüde rol oynarken, askeri bölgelere, haberleşme kablolarına ve turistik alanlara yakınlık uygun bölge seçiminde sonucu etkileyecek derecede değildir. Sonuç olarak, denizüstü rüzgar santrali kurulumu için iki konum uygun olarak bulunmuştur; biri kuzeybatıda, diğeri ise Bandırma körfezinin kuzey doğusunda, sirasıyla $72 \mathrm{MW}$ ve $48 \mathrm{MW}$ kapasitelidir.

(C) 2020 Bandırma Onyedi Eylül Üniversitesi, Mühendislik ve Dağa Bilimleri Fakültesi. Dergi Park tarafından yayınlanmaktadır. Tüm Hakları Saklıdır. 


\section{INTRODUCTION}

Energy is one of the fundamental necessities of the modern life. Because of the increase in world population and development of technological devices, energy consumption is rising constantly. In contrast to the increasing energy consumption, amount of fossil fuel reserves is decreasing. In addition, environmental pollution and greenhouse gas emissions are increasing. These concerns have led countries to search for solutions such as developing renewable energy systems [1]. To address abovementioned concerns, renewable energy sources gained more reputation and importance around the world. Wind, solar, biomass, hydropower, geothermal energy systems can be named as renewable energy sources. Among renewable energy sources, wind energy is one of the most preferable systems because of its high energy production level. Wind energy systems have some advantageous such as the highest energy production systems in per $\mathrm{m}^{2}$, profitability and quick installation among other renewable energy systems. Because of these advantages, wind energy is the most deployed renewable energy system (excluding hydropower energy systems) in terms of installed power capacity globally [2].

Recently, countries which have seashores showed interest in the offshore wind farms. Turkey is surrounded by three different seas but there is not any offshore wind farm yet in the country where there is a great potential to be benefited. In the literature, there are several studies which estimated potential offshore wind energy on Turkish seashores. An offshore study on Aegean Sea, Bozcaaada region was determined as a suitable region and 30 offshore wind turbines with $3 \mathrm{MW}$ power were placed by using WindPro [1]. In another study which applies techno-economic analysis for Turkey offshore wind potential by applying multi-criteria site selection method, the most promising three locations were determined as Bozcaada, Gökçeada and Bandırma [3]. Although the placement wind turbine number and total capacity of Bandırma region were determined as 97 turbines and 349.2 MW, respectively, the ship route impact (from Bandırma to Bursa) was ignored in this study [3]. To determine Turkey's offshore wind potential, 10 different restrictions were applied on 10 regions and the Weibull distribution was conducted for technical wind speed analysis and ideal water depth was selected between 20-50 meters to install offshore wind turbines [2]. Finally, total offshore wind potential of Turkey was calculated in $9 \mathrm{GW}$ by authorities [2]. In another study, technical, economic, and environmental comprehensive analysis was applied to determine offshore wind potential in Turkey considering 11 restrictions by using multi-criteria method [4]. Some studies found that Bandırma bay is one of the suitable offshore locations for wind energy [3,4]. Also, some studies examined the potential of wind energy and economic value of wind energy power plants [5-9]. This study aims to find suitable locations for potential offshore wind farms on the Bandırma bay combining Multi-Criteria-Decision making method and GIS considering different criteria to provide information to the investors and policymakers about the potential locations of one of the new energy production systems in Turkey in the near future.

\section{METHOD}

In this study, the proposed diagram which explains the methodology is shown in Figure 1. The GIS and MCDM method was used the determination suitable site for wind farms [10]. It was handled under three main steps; (i) processing and data collection, (ii) determine restrictions and establish the MCDM method, (iii) evaluation of the impacts for this analysis. To obtain accurate results, updated and comprehensive data sources must be found and also received data must be edited to use in Geographical Information Systems. In this comprehensive study, a lot of data sources was used such as Global Wind Atlas, Emodnet, CLC 2000, Birdmap [11-14]. On the second step, technical and environmental impacts were determined according to current legislation and situation. In this scope, eight standard criteria such as wind speed, depth of the sea, bird migration lines, marine fish and mammals, closeness to military zones, the communication cables, touristic areas and ports and ship routes were applied. After technical and environmental analyses, suitable regions for offshore wind energy potential was determined. 


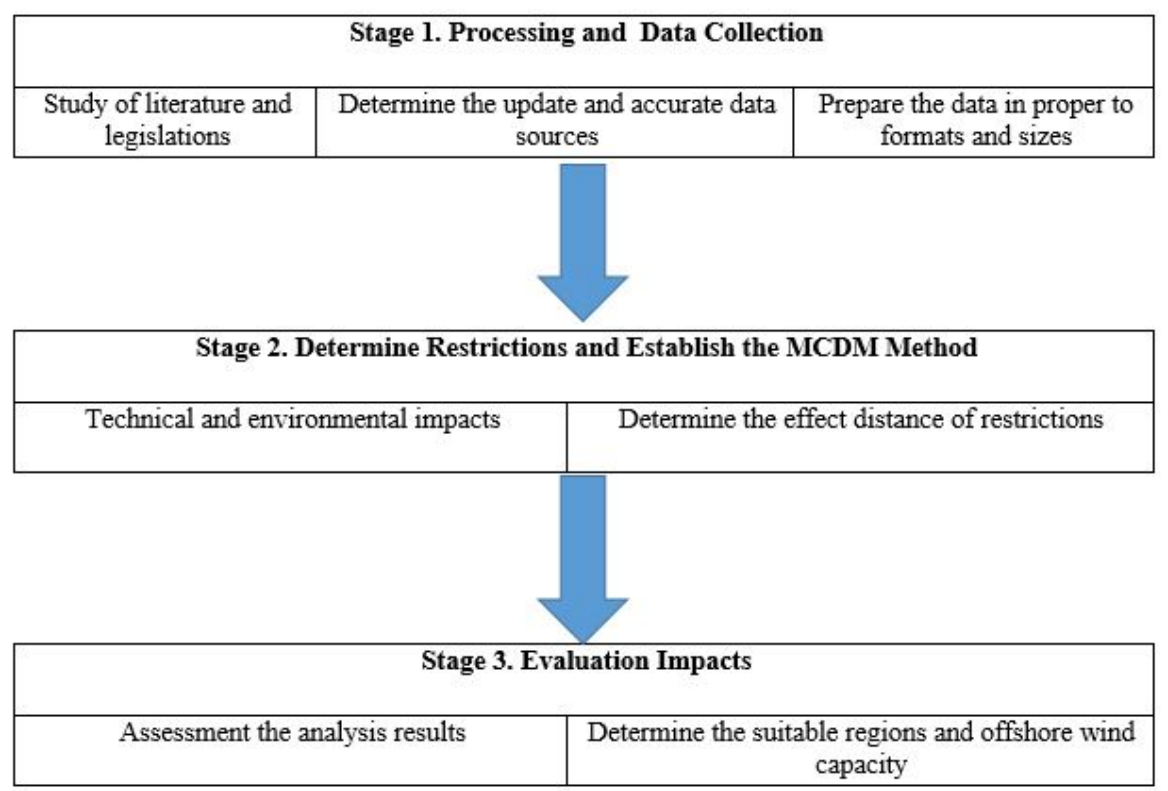

Figure 1. Roadmap of study

\section{RESULTS}

\subsection{Study Area}

This analysis was conducted for Bandırma bay, located northern shores of Balıkesir city. Bandırma is located at a latitude of $40.3^{\circ}$ and a longitude of $27.9^{\circ}$. Because of its geographical position, Bandirma is an important commercial and port region. Also, it has some touristic regions for foreign and domestic holidaymakers. The study area is shown in Figure 2. with grids $(10 \mathrm{~km} * 10 \mathrm{~km})$. Also, there is a tunnel effect in Marmara Sea. Therefore, the wind speed potential is high in the study area and it is worth to be investigated potentiality for offshore wind investments.

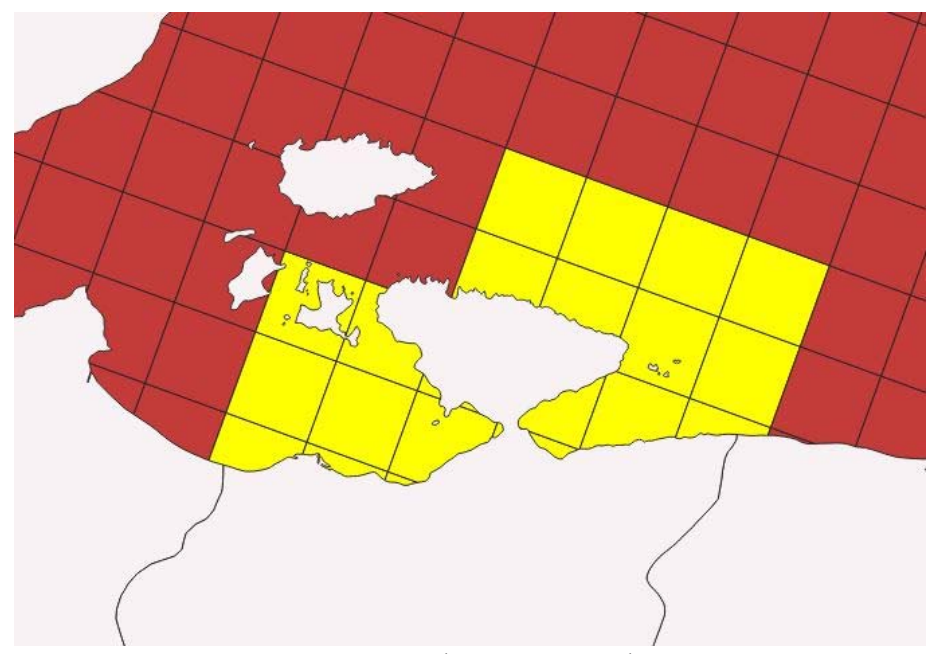

Figure 2. Study Area, Bandirma

\subsection{Technical Assessments}

To determine suitable sites for offshore wind farms, technical analyses are very important. technical assessments were handled with wind speed and water depth analysis. To consider any potentiality for wind farms, the minimum wind speed must be at least $3 \mathrm{~m} / \mathrm{s}$. In addition, to suggest economic efficiency for the wind farms, the minimum wind speed of the area must be around $7 \mathrm{~m} / \mathrm{s}$ [15]. Due to lack of obstacles for disrupting the winds, more stable flow and high wind speed occur in the offshore wind farms [16]. Therefore, the wind speed potential of offshore wind farms is nearly $\% 30$ higher than onshore wind farms. In this study, the necessary data for the wind speed was received from Global Wind Atlas (GWA) at $100 \mathrm{~m}$ elevation. Afterwards, data sets proceed in Geographical Information System (GIS) and finally wind speed distribution map layer was obtained with three different color and shown as legend in Figure 3. The wind speed distribution map layer is shown in Figure 3. According to this 
map layer there is not any region with low wind speed (less than $3 \mathrm{~m} / \mathrm{s}$ ). Also, the blue colored regions are suitable for the offshore wind farms economically (greater than $7 \mathrm{~m} / \mathrm{s}$ ).

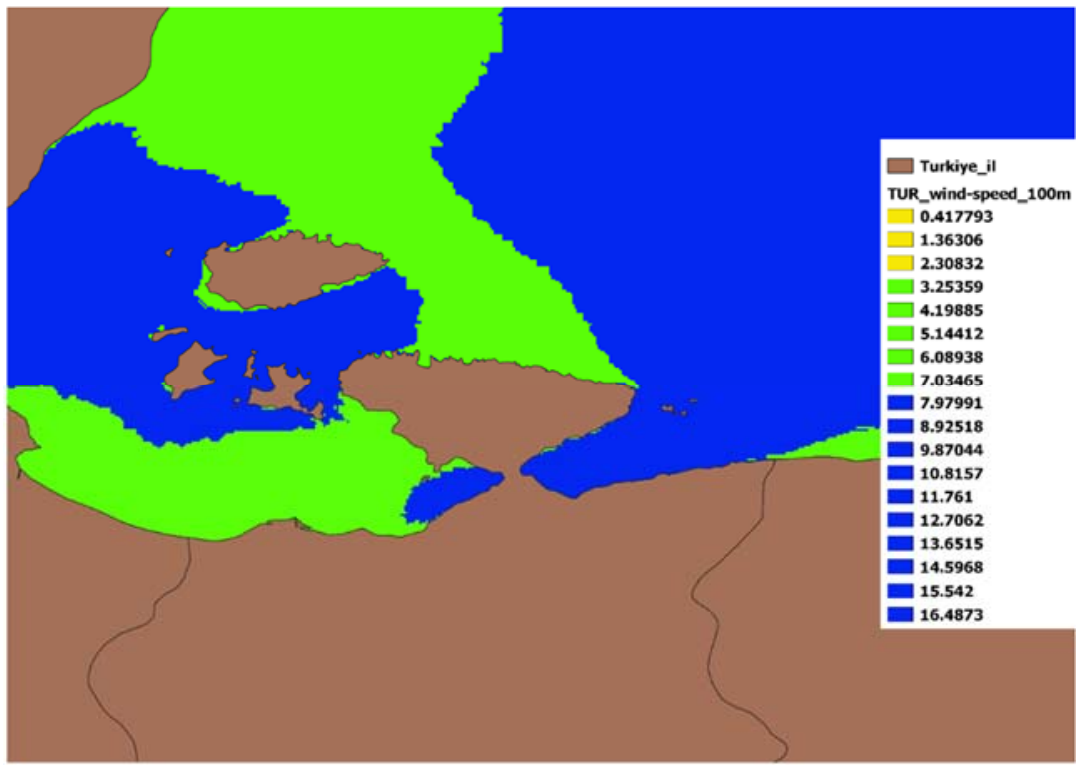

Figure 3. Wind speed distribution map layer in study area

Another important aspect in technical assessments is water depth. Building offshore wind turbines on to seabed process is very hard and laborious. Therefore, the suitable region's water depth must be selected carefully, and the analysis related to water depth must be done in details. In the literature, for offshore wind farms the most suitable regions are considered with water depth of between 20 and 50 meters [17]. With the development of foundation technologies of offshore wind turbines, suitable water depth may reach to 1000 meters. Thereby, offshore wind potential of countries may reach more five times [1]. In this study, maximum water depth for monopile offshore wind turbines was selected as 50 meters. Figure 4 shows that the water depth analysis which was conducted using GIS. Figure 4 shows that Bandirma bay has plentiful shallow area near the shore. Investors and energy planners to build offshore wind farms should consider environmental and social impacts of potential offshore wind farms in the area.

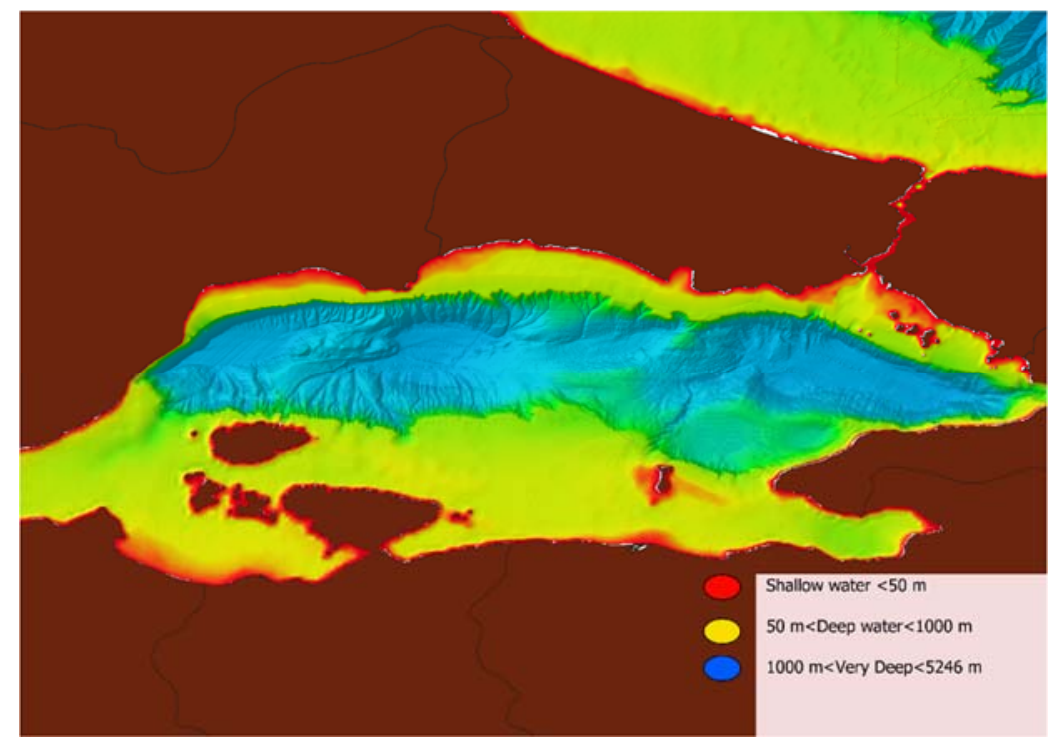

Figure 4. Water depth of Marmara Sea

After wind speed and water depth analyses, it must be determined the suitable regions in terms of technical impacts. Obtained Figure 3 and Figure 4 map layers superimposed by using GIS and shown in Figure 5 which shows technically suitable regions determined in the study area. Determined suitable region's wind speed is greater than $7 \mathrm{~m} / \mathrm{s}$ and water depth is less than 50 meters. According to these restrictions, two technical suitable regions where are located on northeast and northwest of Bandırma bay. 


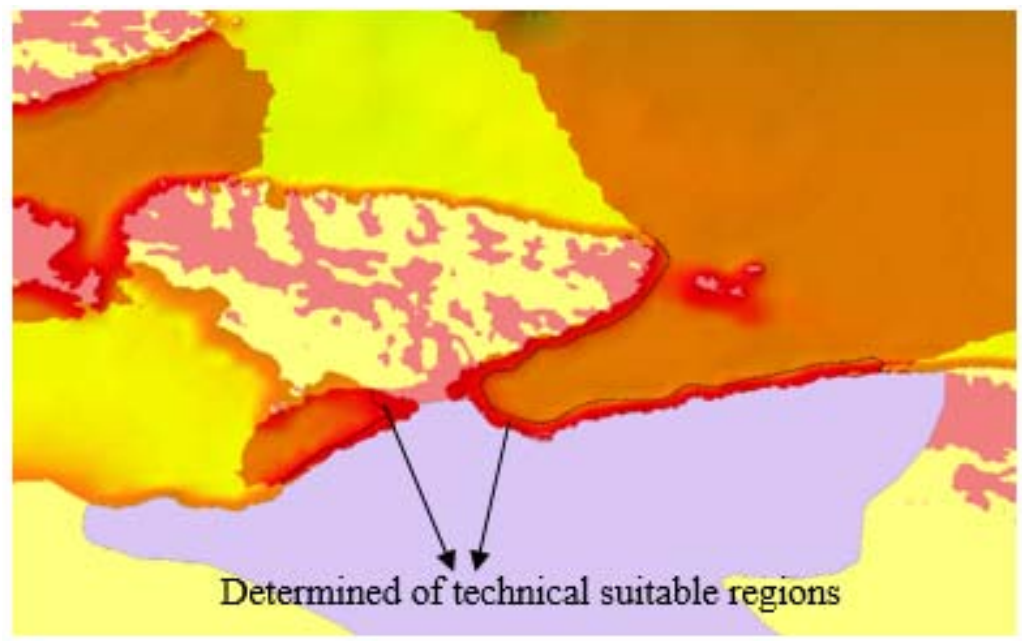

Figure 5. Technical suitable regions

\subsection{Environmental Assessments}

After technical analysis, environmental impacts and restrictions should be considered for offshore wind farms according to region's situations. Environmental assessments should be done in detail and up to date. Generally, environmental assessment studies have more restrictions than technical assessments studies. MCDM and GIS combination method is used to determine the suitable regions for energy power plants such as solar, wind, hydropower and so on [18,19]. In this study, environmental assessment step consisted of pipelines and telecommunication cables, marine fish and mammal's regions, famous tourism regions, main ports, ship routes and ship density, military regions and bird migration paths.

\subsubsection{Military Regions}

The use of military regions for different purposes are prohibited and dangerous, since the military forces use these regions for training, settlement, and other reasons. Estimated and considered locations of offshore wind farms in Turkey must be selected carefully, to not to encounter any disagreement. Therefore, offshore wind farms must be installed far away 5 kilometers from military regions due to potential impact on military operations [20]. The nearest military regions of the study area which is Erdek military region is shown in Figure 6 and its distance of suitable region was calculated as 5.8 kilometers. Therefore, there is no negative effect in terms of military region restriction.

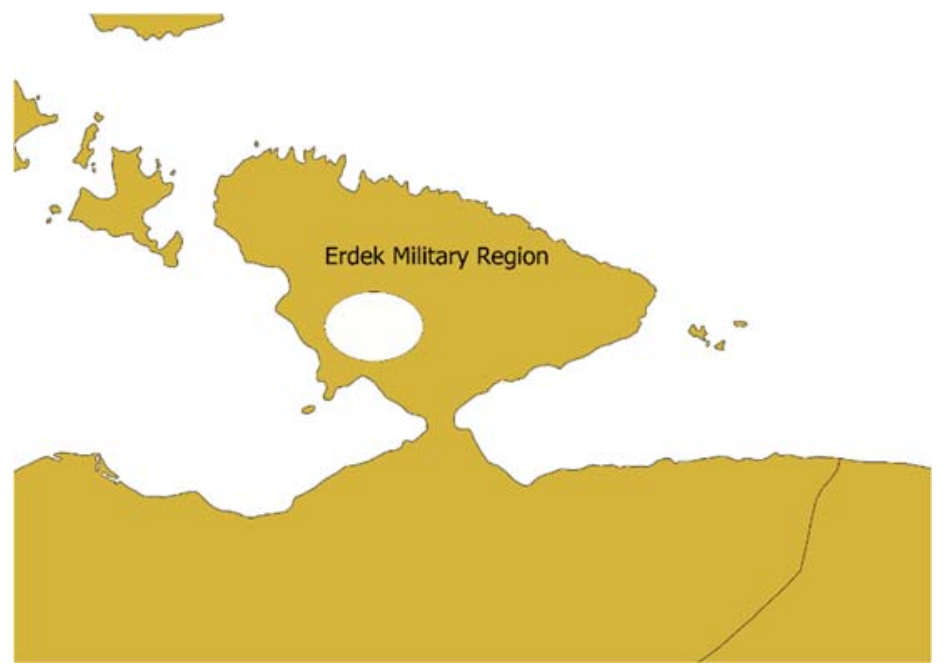

Figure 6. Military regions near the study area

\subsubsection{Pipelines and Underground Cables}

Turkey is located between Europe and Asia. Therefore, Turkey has a critical position in terms of transportation of commercial loads, natural gas, petroleum, and passengers. This enables Turkey to acquire important advantages 
such as natural gas and petrol transition. Petrol and petroleum derivate, which are produced in Iraq and Caspian regions, can be transported by the Baku-Tbilisi-Ceyhan and Iraq petrol pipelines to Turkey [21]. Two main ways of pipelines and telecommunication cables pass through the Marmara Sea. This map layer denoted in Figure 7. The nearest telecommunication cables are far away $20 \mathrm{~km}$ from study area. Therefore, it could be asserted that there is no threat in terms of installation of offshore wind farms on Bandırma bay.

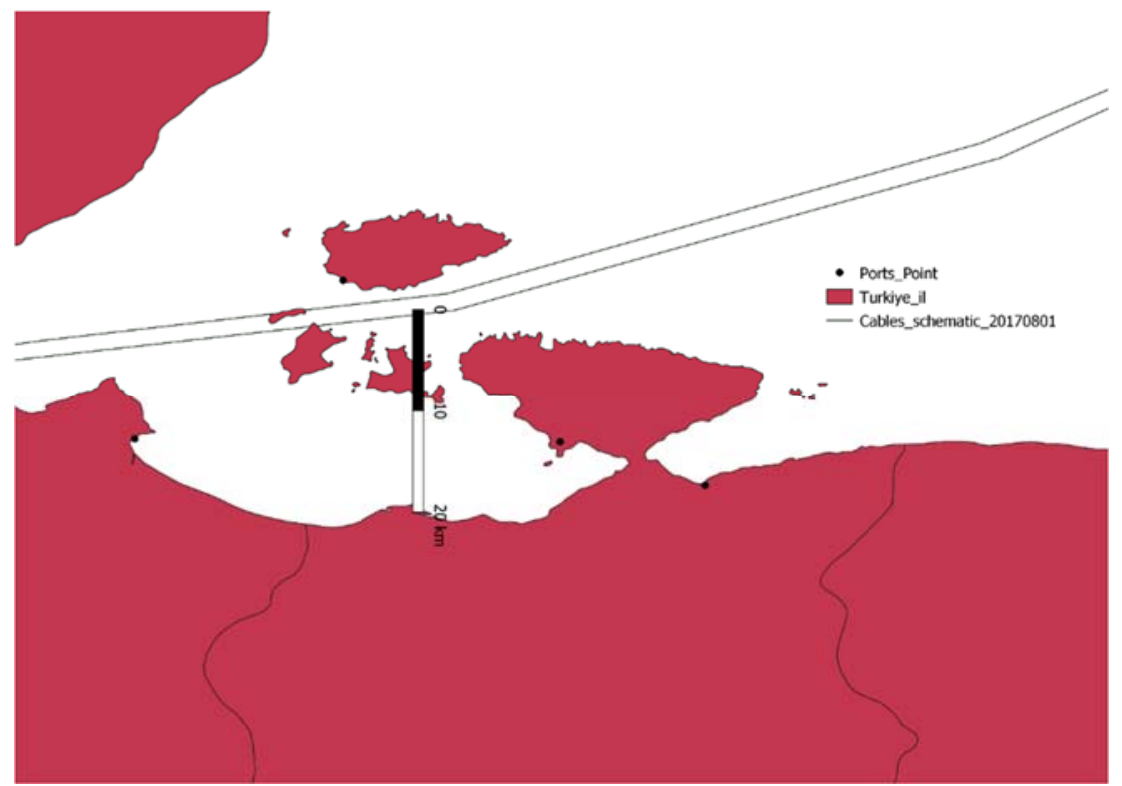

Figure 7. Pipelines and telecommunication cables routes near the Bandirma bay

\subsubsection{Marine Fish and Mammals Regions}

Fishery is very important income type for people who live in near the seas. Offshore wind farms may negatively affect fisheries because of its vibration. However, there is no vital effect on natural fish habitat because the monopile offshore wind turbines which are selected in this study do not create the vibration and noise which disturb marine fish [19]. The fishery zones were divided with lines to show marine mammals and fish regions in Figure 8.

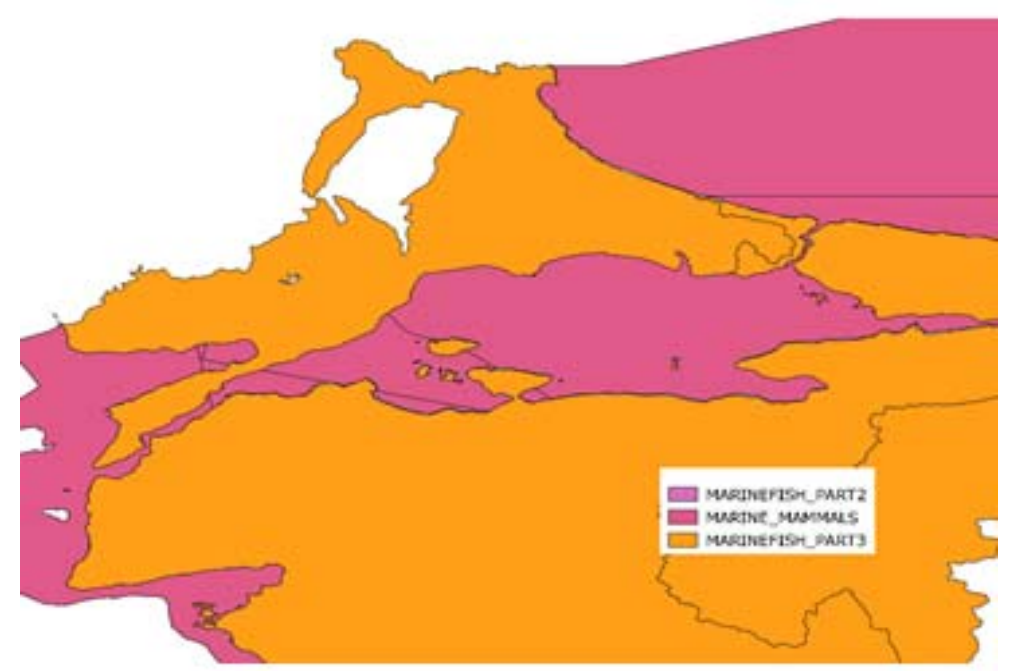

Figure 8. Fishery zones and mammal's regions

\subsubsection{Famous Touristic Regions}

Turkey has four seas which are suitable for swimming and tourism activities. Therefore, fifty million tourists come from different countries to Turkey touristic regions per year [22]. Therefore, suitable site selection of offshore wind farms considers potential negative effects on tourism. In this study, famous beaches and touristic areas nearby the Bandirma bay were determined. There were two famous touristic areas near the study area. However, determined suitable regions do not affect these famous touristic regions since suitable regions with high wind 
speed and shallow water are far away from the touristic areas. Figure 9 illustrates these touristic areas with black lines.

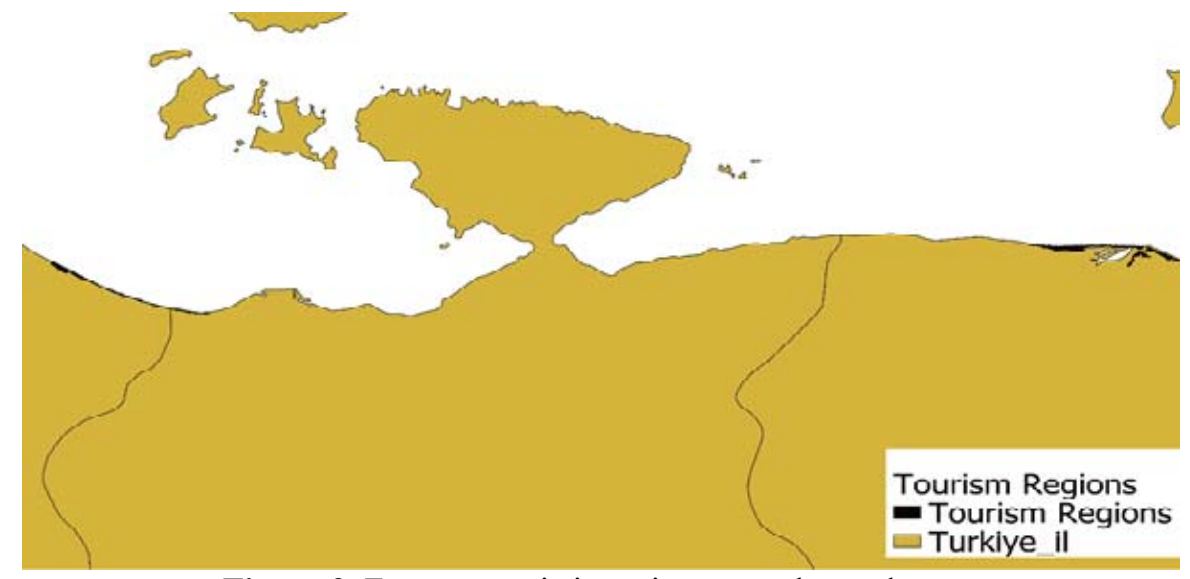

Figure 9. Famous touristic regions near the study area

\subsubsection{Bird Migration Path}

Wind turbines which are located on bird migration paths could kill the migratory birds. Therefore, wind turbines should be located 3 kilometers away from bird migration paths [23]. A layer to use in GIS for bird migration paths map was received from Birdmap which is shown in Figure 10.

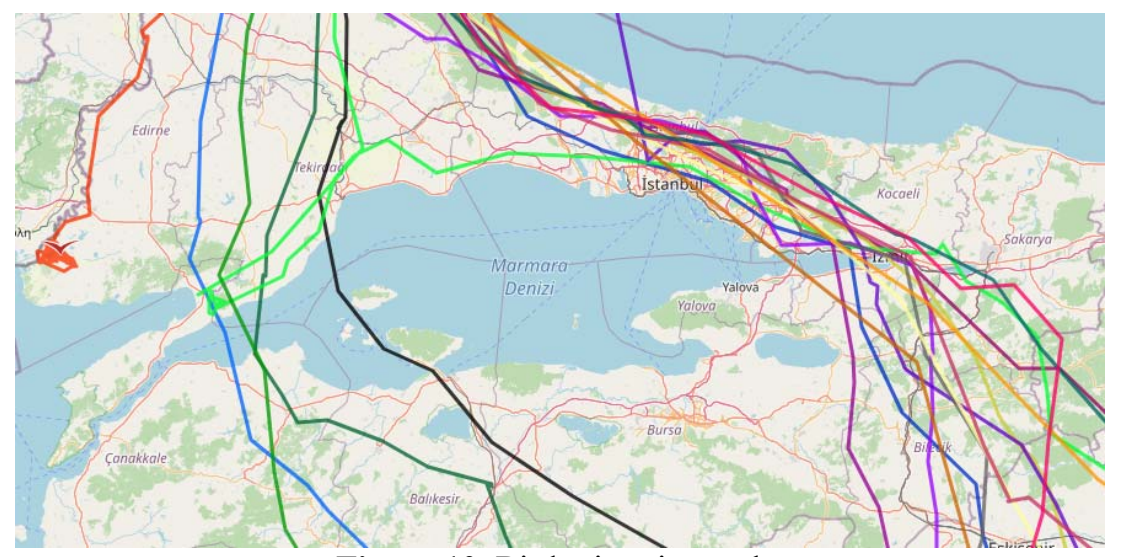

Figure 10. Bird migration paths

\subsubsection{Main Ports, Ship Routes and Ship Density}

The seas of Turkey are used by native or foreign people intensely for different purposes; among those the most important impacts are ship routes and ship density in study area due to having a vital port for commercial passenger traffic, namely Bandırma Port. The analysis of these restrictions was done in details and carefully. Offshore wind turbines might be dangerous and hazardous in stormy conditions. Therefore, suitable regions for offshore wind farms should be $3 \mathrm{kms}$ far away from intensive ship routes and main ports [24]. Main ports and ship density map layer is shown in Figure 11. Green colored regions show the most used ways by sailors whereas other colors show the density of sea vehicles. The left side of the study area has lower density than the other sites. Also, near the shore of Bandirma port, there is a small tunnel as a suitable region.

Bandırma has 7 ship routes because of its location. Also, the Bandırma port is preferred for cargo, passenger, and other ship traffic processes. Generally, Bandırma-Bursa and Bandırma-i̇stanbul routes are very dense. In this region, there are four different ways which limit selecting more suitable regions for offshore wind farms. Additionally, according to analysis results, most of the restrictions are from ship routes for this study area. The ship routes map layer is shown in Figure 12. 


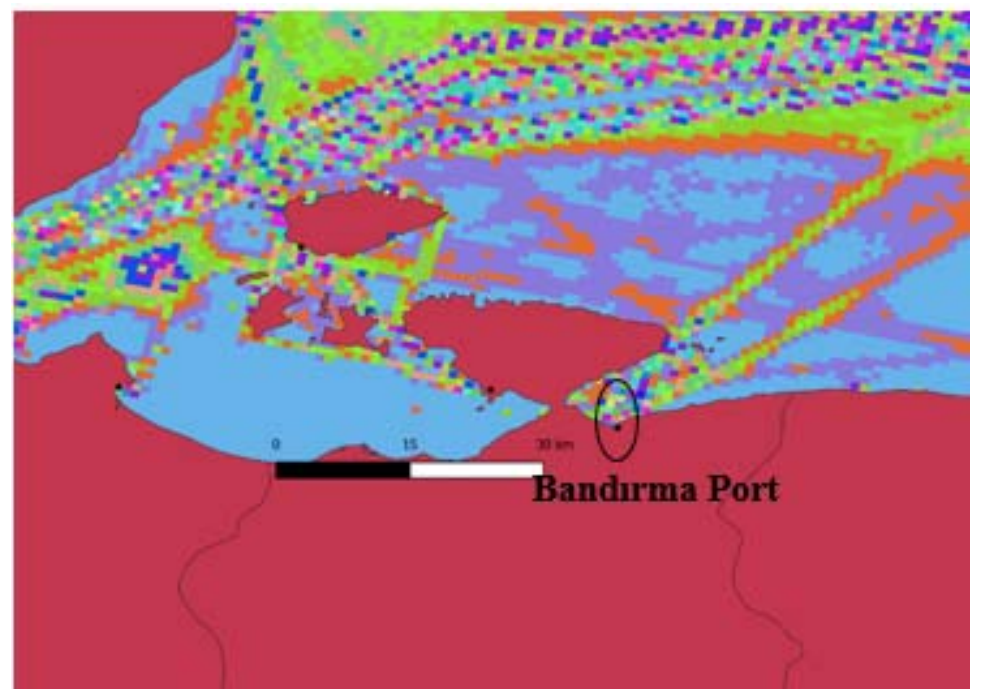

Figure 11. Bandırma port and ship density

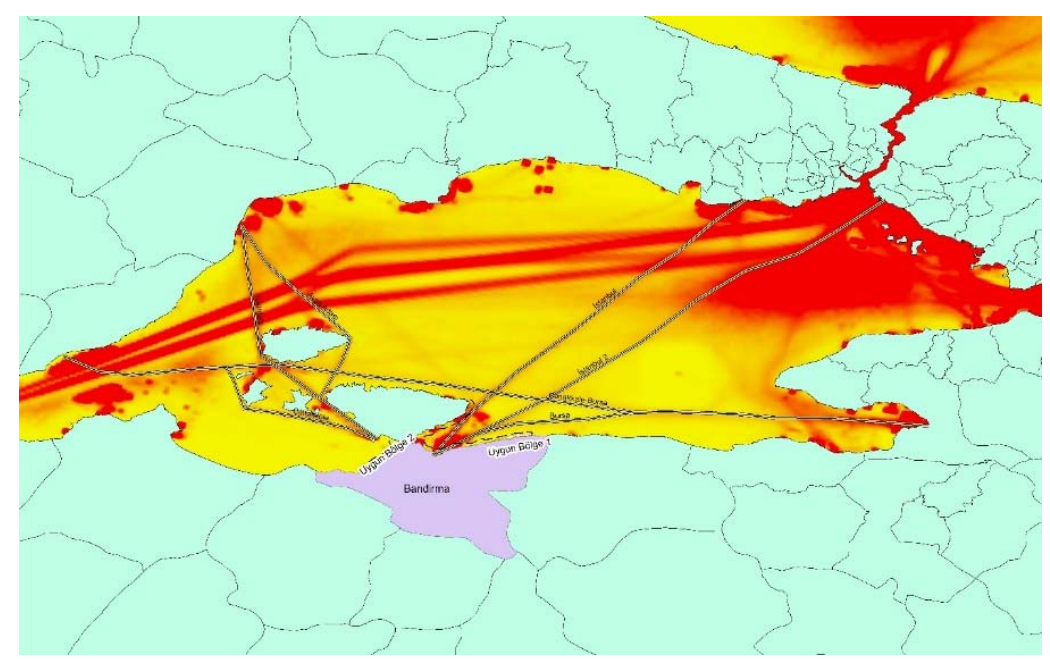

Figure 12. Ship routes map layer

\subsection{Potential Capacity Assessment}

This comprehensive analysis study aimed to develop a tool combining GIS and MCDM combination method to obtain results visually and in a short time. After technical analysis results, technical suitable region's map layer was denoted in Figure 5. Based on the determined technical suitable regions, environmental analysis was done by using GIS and illustrated Figures. 6-12. In this step, it was determined that the most impactful and important restrictions was the ship routes. To estimate the capacity of the determined suitable regions of offshore wind installations, Siemens Gamesa SG6-154 offshore wind turbines were selected and located on to the map (Figure 13). The first region's circumference and area are nearly $21 \mathrm{~km}$ and $10 \mathrm{~km}^{2}$, respectively. The second region's circumference and area are $9 \mathrm{~km}$ and $5 \mathrm{~km}^{2}$, respectively. These values are very important for offshore installations. The power of the selected wind turbine is $6 \mathrm{MW}$ and rotor diameter (D) is 154 meters. Generally, energy planners and investors prefer this offshore wind turbine [25]. Micro sitting process is very important for economic and energy production analyses. Therefore, the distance of offshore wind turbines should be selected carefully. The most appropriate distance is selected as $4 * \mathrm{D}-7 * \mathrm{D}$ meters for vertical and horizontal distances, respectively. According to this information, 12 and 8 offshore wind turbines in region- 1 and region-2, respectively by using WindSim. It is found that the total number of wind turbines is 20 and total capacity is $120 \mathrm{MW}$ and the dominant wind flow is found to be from southwest to northeast. This capacity value is very important and vital to meet of region's electricity demand. 

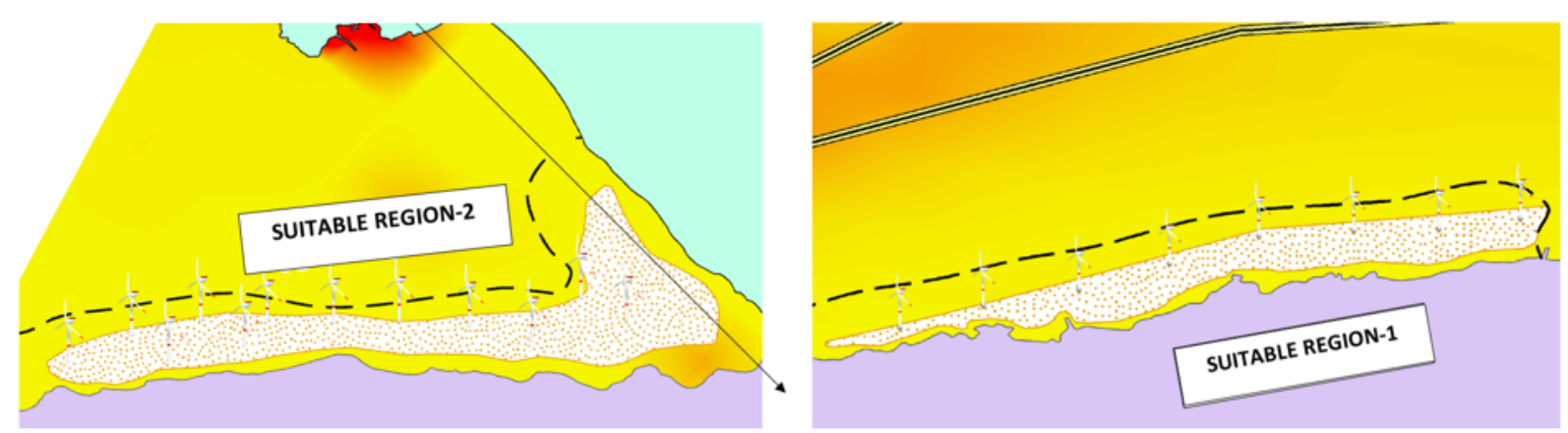

Figure 13. Suitable regions on the Bandırma Bay

\section{CONCLUSIONS}

This study investigated the potential of offshore wind farms on Bandırma bay considering different criteria and applying MCDM and GIS. Following conclusions are drawn from this study:

- Combination of GIS and MCDM enables creating a lot of map layers for analysis of suitability of study area under selected restrictions. Using obtained map layers, the most suitable regions are determined easily and could obtained the visual suitability map.

- Two locations on Bandirma Bay have been determined as potential locations for offshore wind farm installation with total capacity of $120 \mathrm{MW}$.

- With this comprehensive analysis study, investors, decision makers, authorities and energy planners can easily get information and this study can adopt easily to changing updates.

Moreover, Bandırma has a tunnel effect because of its location. Therefore, the offshore wind potential might be higher than calculated in this study. However, the study area has a lot environmental effect. Especially, ship routes affected large areas while determining suitable site selection. Also, one of bird migration paths prevented 3 more offshore wind turbines installation in suitable region-2 which was shown in Figure 13.

Statement of Conflict of Interest: Author has declared no conflict of interest.

Author's Contributions: The contribution of the authors is equal

\section{REFERENCES}

M. Satir, F. Murhpy, K. and McDonnel "Feasibility study on an offshore wind farm in Aegean Sea, Turkey", Renewable and Sustainable Energy Reviews, pp. 2552-2562, 2018.

[2] C. Emeksiz, and B. Demirci "The determination of offshore wind energy potential of Turkey by using novelty hybrid site selection method", Sustainable Energy Technologies and Assessments, vol. 36, 2019.

[3] U. Cali, N. Erdogan, S. Kucuksari and M. Argin. "TECHNO-ECONOMIC analysis of high potential offshore wind farm locations in Turkey", Energy Strategy Reviews, vol. 22, pp. 325-336, 2018.

[4] M. Argin, V. Yerci, N. Erdogan,S. Kucuksari, and U. Cali "Exploring the offshore wind energy potential of Turkey based on multi-criteria site selection", Energy Strategy Reviews, vol. 23, pp. 33-46, 2019.

[5] M S. Genç, M. Gökçek "Evaluation of wind characteristics and energy potential in Kayseri, Turkey", Journal of Energy Engineering-ASCE, vol. 135(2), pp. 33-43, 2009.
[6] M. Gökçek, M S. Genç "Evaluation of electricity generation and energy cost of wind energy conversion systems (WECSs) in Central Turkey", Applied Energy, vol. 86(12), pp. 27312739, 2009.

[7] M S. Genç "Economic viability of water pumping systems supplied by wind energy conversion and diesel generator systems in North Central Anatolia, Turkey”, Journal of Energy Engineering, vol. 137(1), pp. 21-35, 2010.

[8] M S. Genç, M. Çelik, İ. Karasu "A review on wind energy and wind-hydrogen production in Turkey: A case study of hydrogen production via electrolysis system supplied by wind energy conversion system in Central Anatolian Turkey", Renewable and sustainable energy reviews, vol. 16(9), pp. 66316646, 2012.

[9] G. Genç, M. Çelik, M S. Genç "Cost analysis of wind-electrolyzer-fuel cell system for energy demand in Pınarbaş1-Kayseri”, International journal of hydrogen energy, vol. 37(17), pp.12158-12166, 2012. 
[10] M S. Genç "Determination of the most appropriate site selection of wind power plants based Geographical Information System and Multi-Criteria Decision-Making approach in Develi, Turkey", International Journal of Sustainable Energy Planning and Management, vol. 30, pp. 97-114, 2021.

[11] Global Wind Atlas Map (GWA), 2020. https://globalwindatlas.info/

[12] Emodnet Human Activity, 2020. https://emondet.eu/en/human-activities

[13] Copernicus Data Sources, CLC 2000. https://land.copernicus.eu/pan-european/corine

[14] Birdmap, 2020. https:// birdmap.5dvision.ee/en

[15] M. Szurek, J. Blackhowski, A. Nowacha "GIS-based method for wind farm location multi-criteria analysis”, Mining Science, vol. 21, pp. 65-81, 2014.

[16] M. Bilgili, A. Yasar, E. Simsek "Offshore wind power development in Europe and its comparison with onshore counterpart". Renewable and Sustainable Energy, vol. 15, pp. 905-1005, 2011.

[17] A. Arrambide, I. zubia, A. Madariaga. "Critical Review of offshore wind turbine energy production and site potential assessment", Electric Power Systems Research, vol. 167, pp. 39-47, 2019.

[18] H. E. Colak, T.Memisoglu, Y. Gercek. "Optimal site selection for solar photovoltaic (PV) power plants using GIS and AH: A case study of Malatya, Turkey", Renewable Energy, vol. 149, pp.565-576, 2020.
[19] F. Ferrari, G. Besio, F. Cassola, A. Mazzino. "Optimized wind and wave energy resource assessment and offshore exploitability in the Mediterranean Sea”. Energy, vol. 190, 2020.

[20] M. Deveci, E. Ozcan, R. John. "Offshore wind farms; A fuzzy approach to site selection in a Blach Sea region". IEEE Conference, College Station, TX, USA, 6-7 February 2020.

[21] O. Akdag and C. Yeroglu. "An evaluation of an offshore energy installation for the Black Sea region of Turkey", GG. Science and Technology, pp. 531$544,2020$.

[22] Turkey Tourism Statistics, 2020. https://yigm.ktb.gov.tr/TR-9851/turizm

[23] R. Zimmerling, C. Pomeroy, M.V. Entremont, C.M. Francsis. "Canadian estimate of bird mortality due to collisions and direct habitat loss associated with wind turbine developments". Avian Conservation Ecology, vol. 8:2, pp.10-22, 2013.

[24] M. Mahdy, A. Bahaj. "Multicriteria decision analysis for offshore wind energy potential in Egypt". Renewable Energy, vol. 118, pp.278-289, 2018.

[25] I. Arrambide, I. Zubia, A. Madariaga. "Critical review of offshore wind turbine energy production and site potential assessment", Electric Power Systems Research, vol. 167, pp. 39-47, 2019. 